\title{
A multi-disciplinary perspective to nuance the narrative of tree planting as a nature-based solution
}

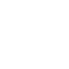

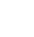

.

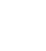

.

8

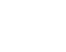



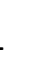

2

3

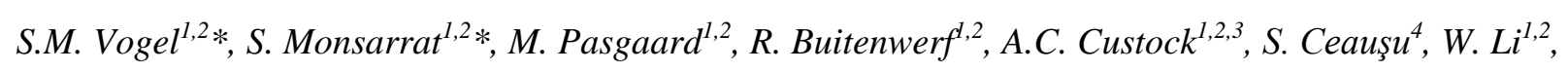

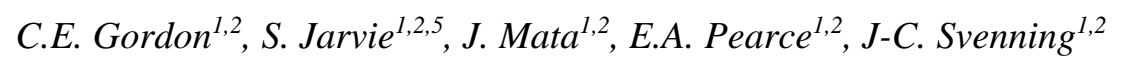

${ }^{1}$ Center for Biodiversity Dynamics in a Changing World (BIOCHANGE), Department of Biology, Aarhus University, Ny Munkegade 114, DK-8000 Aarhus C, Denmark

${ }^{2}$ Section for Ecoinformatics and Biodiversity, Department of Biology, Aarhus University, Ny Munkegade 114, DK-8000 Aarhus C, Denmark

${ }^{3}$ Anthropology Department, Aarhus University, Moesgaard Alle 20, 8270 Højbjerg, Denmark

${ }^{4}$ Centre for Biodiversity and Environment Research, Department of Genetics, Evolution and Environment, University College London, Gower Street, London WC1E 6BT, UK

${ }^{5}$ Otago Regional Council, 70 Stafford Street, Dunedin 9016, Aotearoa New Zealand

*These authors contributed equally to this work

\section{Abstract}

From global nature conservation policies to carbon off-set private initiatives, the focus on tree promotion, and tree planting in particular, as a nature-based solution to global environmental crises such as climatic change and biodiversity loss dominates the current discourse. Yet, this fixation on trees does not reflect a scientific consensus on the benefits of tree planting across diverse ecosystems and can have problematic implications from both an ecological and socio-political perspective. In this paper, we synthesise cross-disciplinary insights to challenge the common storyline of tree planting as a one-size-fits-all, nature-based solution to climate change and biodiversity loss. We discuss the appeal of tree planting as a panacea, and how this conflicts with reality, in which a diverse range of stakeholders represent various perspectives and pursue a plurality of goals. We assess the communicative aspects of trees and forests, exploring the symbolic power of a 'tree' and how practices in remote-sensing and scientific modelling reinforce the dominant tree planting narrative. We then reflect on the ecological and human contexts that need to be considered in planning of tree planting and how historical ecological baselines continue to influence ecosystem management goals. Finally, we explore how current conservation narratives value forest over other kinds of nature and demonstrate the important - but overlooked - role that non-forest landscapes such as open and semi-open vegetation play in climate change mitigation and biodiversity conservation. We conclude that we need to rethink the dominant tree-planting narrative, being mindful and critical of the socio-political drivers behind tree planting initiatives and potential biases, and allow ecological and sociocultural contexts to inform tree-promotion efforts and appropriateness. 
Climate action failure and biodiversity loss are in the top five risks to the global economy and society (World Economic Forum, 2020). As a result, ambitious environmental policies are being proposed, aiming to address the dual crises of climate change and biodiversity loss. This shift towards green policies has led to a renewed interest in nature-based solutions ( $\mathrm{NbS}$ ): actions to protect, manage and restore ecosystems with the objective to address major societal challenges, while providing a range of benefits for people and the ecosystems on which they depend (Seddon et al., 2020b). The use of trees as carbon sinks to remove significant amounts of greenhouse gasses from the atmosphere has been a focus of much interest in the public, scientific and political spheres (Bastin et al., 2019; Keesstra et al., 2018). Policy reports, like the renowned Stern Review on the Economics of Climate Change, promote tree planting as 'an excellent long-term policy', and state that forest cover can be increased cost-effectively in most areas of the world, promoting avoided deforestation, reforestation and afforestation (Stern, 2007). More recently, the European Commission 2030 Biodiversity Strategy 'Bringing nature back into our lives' proposes to plant at least 3 billion additional trees in the EU by 2030 (European Commission, 2020). Recommendations to achieve these objectives range from the promotion of large-scale reforestation (tree planting in previously forested areas), afforestation (creation of newly forested areas), and tree plantations to increase tree cover globally. As such, planting trees has become a generalizable and universalized technology as an NbS to address climate change. This current focus on tree planting has been addressed and criticized both from a socio-political (Griscom et al., 2020) and ecological (Friedlingstein et al., 2019; Veldman et al., 2019) point of view, but an integrated conversation between these disciplines is still missing. Here, we explore this topic from a broad and multidisciplinary perspective, exploring how trees came to dominate the $\mathrm{NbS}$ discourse, and offering alternative narratives to tree planting as a one-size-fits-all $\mathrm{NbS}$.

For illustration, seven percent (290 million ha) of the forest area worldwide are plantation forests, of which 45\% (131 million ha) are planted in intensively managed plantations established mainly for productive purposes (UNEP and FAO, 2020). The type of tree planting depends on the motives behind the planting, yet in current tree planting initiatives or promotion, this distinction is not always clear (Faruqi et al., 2018). Tree plantations for biofuel production and for forest restoration are both considered as $\mathrm{NbS}$ (Seddon et al., 2020a). Therefore, in this manuscript we will refer to tree planting in general, unless otherwise specified. We also do not consider 'forests' to be binary defined by a certain tree threshold, but use this term to refer to forest and woodland ecosystems with complex ecosystem functions and biotic composition (Griffith et al., 2017; Swanson et al., 2021).

While some scientists promote tree planting as the solution to climate change mitigation (e.g. Bastin et al. 2019), others have called for caution to indiscriminate implementation. They warn of potential undesirable 
outcomes and generally argue against tree planting as a simple solution to all environmental crises ( see e.g. Bond et al., 2019; Griscom et al., 2020; Lewis et al., 2019; Seymour, 2020; van Noordwijk, 2020). Regardless of the intentions behind tree planting and obvious benefits given the right circumstances, these initiatives become problematic when they are promoted as a simple, silver-bullet solution to overcome a range of environmental problems (Holl and Brancalion, 2020). Without considering their ecological context, planting trees does not automatically yield functional forest ecosystems, and the capacity of trees to contribute as $\mathrm{NbS}$ to environmental issues depends on considering this ecological context alongside socio-political contexts (Griscom et al. 2020). Furthermore, tree-planting initiatives can lead to undesirable outcomes and come at great social and environmental costs, e.g. rapidly growing trees can result in limited water availability and agriculture can be displaced, spurring deforestation in other areas (Cao et al., 2009; Holl and Brancalion, 2020). The promotion of trees as a win-win solution could also be used as justification to override socio-economic rights, such as land rights of Indigenous and local communities (Griscom et al. 2020).

The objective of this study is to deconstruct the narrative of tree promotion as universal $\mathrm{NbS}$, and to offer nuanced alternatives to consider. We bring together knowledge and arguments from a wide variety of fields such as ecology, political ecology, anthropology and remote sensing to 1) understand this appeal for trees as a one-size-fits-all $\mathrm{NbS}$; and 2) offer alternative narratives, highlighting how the context in which tree promoting initiatives take place matters, and discuss the potential for other biomes, beyond closed forests, to be used as $\mathrm{NbS}$. In doing so, we do not object to the promotion of tree promotion altogether, but aim to deconstruct tree planting as a one-size-fits-all solution to environmental problems and offer alternatives to addressing global environmental crises.

Trees and tree planting in particulars have been emphasized as a general and universal solution to environmental problems, but how did this simplified narrative come to dominate the $\mathrm{NbS}$ discourse? In this section, we explore how the indiscriminate promotion of trees reveals a misrepresentation of the diversity amongst stakeholders and perspectives involved in tree planting (Evans, 2009). We first explore the appeal of trees as a universal symbol to solve climate change and biodiversity loss. We then provide more detail on how different stakeholders have adopted these symbols, and how tree planting becomes understood and negotiated within a science-policy interface. Finally, we describe how global forest models are reality-making, allowing trees to be imagined as generic and discrete individuals, together comprising a 'global forest'.

\section{The appeal of trees as a one-size-fits-all nature-based solution}


101 As a human-focused solution, trees are seemingly easy to control and measure, and therefore appealing to 102 progress-driven initiatives, allowing stakeholders to actively participate and 'success' to be reported. However, 103 the success of tree-planting initiatives for instance are rarely publicly reported in terms of sapling survival rates 104 or maturation percentages. Instead, success is often reported as the number of trees initially planted, benefitting 105 from being fast, easily communicated, and most importantly, visible to wider stakeholders and the public ${ }^{1}$. 106 Indiscriminate tree planting narratives generate easily understandable public benefits, crafting trees into 107 hopeful environmental symbols, regardless of native/non-native classifications of planted species (Evans 108 2009). These shared symbolic generalisations of tree planting can further reinforce group commitment to the 109 tree planting as a panacea paradigm (Wiersum, 1999). Symbols do not hold meaning in itself, but the meaning 110 of a symbol is shaped by those that use it, which makes it possible for a commonly accepted symbol to capture 111 a wide diversity of meanings. This allows users to share the symbol of trees as NbS, while each holding on to 112 their own meaning and motives (Cohen, 1985).

113 Trees and forests share a long history of symbolism across cultures, which partly explains their attractiveness 114 as NbS. Trees have presence in myth and folklore, sacrosanctity in religion and represent powerful 115 commodities in times of war (Konijnendijk, 2008; Wiersum, 1999). Today, forests are still considered in such 116 symbolic terms, as places of inspiration, meditation and retreat (Konijnendijk, 2017). The understood 117 'holiness' and importance of trees, therefore, is an important reason as to why the story of trees is so attractive. 118 Stemming from the Enlightenment, Western tree symbolism and sanctification can be understood in relation 119 to knowledge-producing entities of the world, creating a universal 'Nature' through generalising and scientific 120 unification practices that work on a global systems scale (Tsing 2005). By recognizing the intertwined and 121 irregular development of tree symbolism in various historic, cultural, economic and technological contexts and 122 scales, we can place tree planting and protection into an inclusive narrative, reflective of the diversity of 123 stakeholders and meanings they assign to trees.

125 While there are records of tree planting occurring as early as ca. 10,000 years ago (Hauer et al., 2008), 126 around 3000 years ago China is known to become the world leader in tree planting, and to be the first nation 127 to appoint a specialized service in charge of forest preservation and reforestation (Evans 2009; Konijnendijk

\footnotetext{
${ }^{1}$ Some examples: https://www.bbc.com/news/uk-scotland-north-east-orkney-shetland-51265370, https://www.worldwildlife.org/initiatives/reforestation-grants, https://www.edinburghairport.com/about-us/media-centre/press-releases/2009/03/04/edinburgh-airporthelps-local-schools-to-do-their-bit-for-the-environment
} 
2017). Over time and across regions of Earth, the stakeholders and motives behind the dominant tree planting narratives have varied. Yet, in the history of tree planting as a global discourse, the worldwide exploitation and devastation caused by European colonial powers, followed by the industrial scale of tree plantations in the last century, have been of driving influence (Wiersum 1999). In Europe, tree planting was mainly initiated and controlled by professional foresters and governing bodies (Cernea, 1992). In this tradition, trees are considered as crops, or solutions to environmental degradation associated with resource extraction, e.g. reduce soil erosion and climate regulation (Wiersum 1999). The establishment of this formal 'scientific' forestry sectors and their associated silviculture practices in Europe coincided with the global expansion of European rule over the last few centuries (Fernow, 1911; Agnoletti et al. 2000). As such, industrial extraction and tree restoration activities have a historical linkage in state-making projects (Tsing, 2005). It is pointed out that this is also the time the narrative of tree planting as a panacea was widely embraced and started to be used in biopolitics (Davis and Robbins, 2018). After the Second World War, which led to the destruction of tree plantations around the world, a combined effect of increased international institutionalization, decolonisation and restoration resulted in tree planting on large scales (Evans, 2009; Stilgenbauer and McBride, 2010). Even in post-colonial independence colonial legacies have remained to influence current day forestry sectors and tree planting initiatives across the world (Davis and Robbins, 2018; Devine and Baca, 2020; Enuoh and Bisong, 2015; Sivaramakrishnan, 1995).

Urbanisation in the last centuries has increased societal pressures on forest management, giving rise to a focus on valuing tree planting as a form of social and environmental public good, in particular near urban areas (Konijnendijk 2000). Both the root causes of deforestation, and tree planting as a solution to tree loss and climatic changes, subsequently 'leaked' outside of the realms of forestry (Cernea 1992). This has resulted in an evolution within forestry practices towards social forestry that is people-centred instead of forest-centred (Wiersum 1999). Different groups involved in the promotion of tree planting attach different cognitive beliefs and normative values to trees (Buijs, 2009), resulting in different tree planting goals and strategies (Evans 2009). In recent years, the stakeholder group involved in tree planting has become even more diverse. Governance has shifted from national governments to supra-national (e.g. EU) and regional levels, and to markets and civil societies. This has resulted in a plurality of stakeholders involved in nature management, each with their own values and actions (Keulartz et al., 2004; Pasgaard and Mertz, 2016). Signs of the increase of non-state actors' involvement in forest management can be found across continents. Previous state dominance led to forests to be considered as 'political forests', emphasising that forest are never neutral, but continuously co-produced through power dynamics such as territorialisation, knowledge claims or even violence (Peluso and Vandergeest, 2020, 2011). However, the global environmental governance resulting from the shift in actors can be described as 'green neoliberalism', as it is characterised by a redefinition of political forest as part of market-based solutions to environmental crises (Devine and Baca, 2020). 
Over the last decade, the participation of citizens in global environmental governance has increased, which has led to the development of different types of civic environmentalism (Bäckstrand and Lövbrand, 2006). Some movements are mainly focused on speeding up environmental action with, for example, tree planting initiatives, while others desire change in power dynamics and aim for both a more eco-centric and just world (Bäckstrand \& Lövbrand 2006). These changes of focus and strategies, promoting people and planet rather than production, have reshaped the common perceptions of trees. The tree has become a symbol of improved social well-being and climate action. This narrative enables a degree of social power to be gained by those involved in planting initiatives, and those benefiting from the planted trees, especially in urban areas (Konijnendijk 2017). Various actors have adapted this discourse, from politicians (see below) and companies (e.g. airport $\mathrm{CO}_{2}$ offsetting schemes) to scientists (Newton et al., 2016) and the media ${ }^{2}$. Tree planting is considered as a positive contribution to those with vulnerable livelihoods, and international donor communities promote the planting of trees as a means towards climate change resilience (Etongo et al., 2015). However, despite an increased participation of non-state actors in forestry and forest planting and protection initiatives, community-based programmes do not necessarily provide equal social outcomes (Lund, 2015).

Recently, many recent global initiatives have demonstrated strong political will for achieving ambitious targets promoting trees for the sake of climate change mitigation and/or resilience, and/or to counter biodiversity loss. Most notable of these are (i) the Reduced Emissions from Deforestation and Degradation (REDD+) led by the UN and the World Bank aiming to reduce tropical deforestation by creating financial incentives through carbon trading (UN-REDD 2018); (ii) the Bonn Challenge - launched by the International Union for Conservation of Nature (IUCN) and Germany in 2011 and currently involving 56 nations with a global objective of restoring 150 million hectares of deforested and degraded land by 2020 and 350 million hectares by 2030 (https://www.bonnchallenge.org/); (iii) the 2014 New York Declaration on Forests, which pledges to halve deforestation by 2020 and end it by 2030 (http://forestdeclaration.org/); (vi) and the Trillion Trees Partnership - a 25-year initiative to restore one trillion trees by 2050 (https://www.trilliontrees.org/). The financial rationale for participating in such tree promotion is unmistakable: According to the Organisation for Economic Co-operation and Development (OECD), restoring 46\% of the world's degraded forests could provide up to US\$30 in monetary benefits for every dollar spent (World Economic Forum 2020). Besides tree promotion in large-scale public initiatives, private projects promoting trees have proliferated, driven by a combination of consumer demands, environmental stewardship, legal regulations and green branding benefits. Additionally, initiatives based on tree planting tend to gather strong public support. A campaign launched by social media

\footnotetext{
${ }^{2}$ Exemplified with a news article headline stating how some Danish political parties ' $[\ldots .$.$] will buy out farmland and$ plant forest', but in the article itself, the word 'forest' is only mentioned once by one of the politicians. https://www.dr.dk/nyheder/politik/stoettepartier-med-krav-til-finansloven-vil-koebe-landmaends-marker-og-planteskov
} 
influencers in partnership with the non-profit organization Arbor Day Foundation illustrates this positive attitude of the public towards tree planting. The campaign gathered over 800,000 supporters and raised over \$20 million in less than two months to plant 20 million trees around the world (https://teamtrees.org/).

\subsection{Tree planting dominance in the science-policy interface}

Environmental narratives that play a dominant role in shaping societal debates, such as the climate-change policy discourse, are influenced by scientific expertise, but also by their societal and environmental context (Wesselink et al., 2013). Scientists can influence political debates by supplying knowledge, bridging between knowledge producers and users, or facilitating an integration of knowledge production and use (Turnhout et al., 2013). These interactions between science and policy result in knowledge production, decision-making and implementation, which are not linear processes but dynamic co-productions, with unclear boundaries between the two realms (Lövbrand, 2007; Wesselink et al., 2013). Furthermore, with the rise of interface organisations like tree planting NGOs that engage, exchange, collaborate, explain and reward between both sides of the science-policy nexus, an increased flow of scientific knowledge and environmental policy awareness enters into society at large (Osmond et al., 2010). How experts, journalists, civil society organisations and policy makers frame environmental-anthropogenic complexities such as climate change, and their reaction to these, is crucial in the shaping and success of responses to climate change (Dewulf, 2013). If climate change is consistently framed as a technological challenge or as a 'wicked problem of governance', this also influences the type of response and adaptation strategies (Dewulf, 2013; Li, 2007). Once dominant, discourses can suppress alternative knowledge claims and policy discourses and their implementation (Wesselink et al. 2013). For example, promoting trees as part of such discourse could divert attention away from behavioural change, e.g. reduced consumption of fossil fuels (Becken, 2004). Planting then becomes a quick fix (relatively speaking), which is convenient to visualize and comprehend, as argued in the following.

\subsection{The representation of trees in remote sensing-based global forest models}

Global forest models based on satellite remote sensing (SRS) near real-time images have become indispensable in environmental research/monitoring by revealing otherwise invisible narratives of expansive and long-term forest transitions (Tabor \& Hewson, 2018). However, the political ecology of these models and their vitality in shaping environmental discourse and symbolism deserves attention (Bennett 2010). Dominant earth system models in general hold strong social shaping power due to their discursive authority and centrality within the science-policy interface (Peterson 2000; Edwards 2010; Hulme 2013). Just as global climate models are central in making global climate a knowable entity, global forest models make forests into a global, knowable entity- rather than forests as local, or regional systems at best. Similar to other earth systems models, global forest models capture core interlocking elements of what a globally scaled forest 'is', transforming forests into a knowable 'whole' by smoothing out data through an overarching reference frame provided by the model (Edwards 2000). For an SRS-based model to assemble forests into a global 'whole', a simplistic definition of 
what a forest 'is' is epistemically required for stitching together satellite images into a 'global forest'. Once the model enters a digital interface, however, it can be 'credited with the irrefutability of unmediated information'- as environmental historian Richard Hamblyn (2009: 232) writes on graphic representations of climate models. In other words, the model's ability to illustrate a 'global forest' becomes a 'found' object, rather than "made" artefact, which holds the capacity to underpin negligent tree-planting decisions (Tufte 1983).

Although many SRS-based global forest models exist, the majority emphasize deforestation and forest degradation, while the inclusion of functional characteristics or global, long-term forest transition and restoration - such as spontaneous regrowth or ecologically 'rewilded' - have remained minimal (Chiarucci and Piovesan, 2020). One of the most popularly used, and publicly accessible, SRS-based global forest models is Global Forest Watch (GFW) (Hansen et al., 2013). GFW provides an annual estimation of global tree-cover changes at a spatial resolution of 30m based on long-term observations of Landsat satellite data since 2000. To model global tree-coverage, GFW uses the spectral reflectance signatures of $\geq 5 \mathrm{~m}$ aboveground biomass. While accurate (Zhang et al., 2020), ecosystem heterogeneity that falls outside of GFW's algorithm - where forests are defined as closed tree crown-cover vegetation $\geq 5 \mathrm{~m}$ - is flattened into a forest/no forest binary. Savannah systems, for example, are challenging to study via SRS due to the complex relationship between trees and grasses in these biomes, forming a scattered distribution of woody vegetation (Zhang et al., 2019). GFW's algorithmic binary holds limitations when detecting human-planted forests (Tropek et al., 2014), although improvements have been made (Petersen et al., 2016). As a result, GFW's capabilities of detecting coarse forest-change may require supplementary remote sensing products to assess regional ecological complexity. For example, to assess carbon sequestration patterns of dynamic multi-use sub-tropical forests in southern China, Tong et al., (2020) provides a comparison of GFW with the Chinese high resolution satellite data $(2 \mathrm{~m})$, and a more advanced classification system on different forest types that includes both planted and natural regrowth forests. Through this comparison, Tong et al. (2020) were able to show variations in aboveground biomass and forest dynamics, complicating simplistic forest definitions by providing alternative classifications for what a forest 'is'.

GFW is undeniably a valuable and versatile tool: by simplifying forests, forests can be globally articulated and integrated into predictive models, such as climate or habitat suitability, allowing for forests as a global entity to participate in what sociologist Fine (2007) calls 'future work'. However, with a simplified ontology for what a forest 'is', a tree is also able to be transformed into a scalable, a contextual and autonomous unit of biomass, epistemically nestled within a climate mitigating, and 'Nature-making', 'global forest'. For example, by merging GFW with other land-cover layers, Bastin et al. (2019) establishes a global tree restoration potential which emphasizes tree-cover rather than contextualized forests or other nature-types, such as grassland, woodland and savannah systems into estimates of a forest restoration potential and carbon storage (Veldman 
et al. 2019). GFW's dominance within a web of integrated models enlists it as both an authoritative model for implementing tree-promoting initiatives, such as REDD+, and as an absolving advocate for companies economically invested in plantation forests, such as Unilever collaborating with GFW (Tabor \& Hewson 2018; Hume 2014). While SRS-based global forest models are essential for establishing strong truth-claims, they have also become a durable technological component within a global knowledge infrastructure that has reinforced a bias towards negligent tree-planting in global governance strategies due to the epistemic limitations embedded into these models and their social shaping power going unrecognized. Going forward, a greater attention toward the limitations of such models is needed, as they reinforce particular types of realities. Supplementary products to express regional contexts and their complexities need to be developed and used alongside dominant models that enable and shape global environmental governance strategies, as they may provide a critical vantage point for rethinking indiscriminate $\mathrm{NbS}$.

In order to achieve a wide range of benefits for climate and biodiversity, tree promotion schemes need to consider the broader context in terms of 1) historical context and the appropriate baseline to use as a reference point to define targets; 2) the ecological context in terms of species composition (what), the environmental conditions (where), and the type of management (how) required to ensure the long-term success of initiatives; and 3) the socio-political context in which the decision-making process is situated (why and who).

\subsection{Historical context: Shifting baselines in tree planting}

Despite the recent surge in media attention and initiatives, planting trees is by no means unique to our time (Evans 2009). The long history of human impact on forest composition complicates the selection of a reference point to guide the choice of restoration targets and tree planting objectives. Most biodiversity monitoring schemes do not go further back than the end of last century (Mihoub et al., 2017), but failing to integrate the long-term dynamics that gave rise to contemporary landscapes risks misunderstanding the complexity of social and environmental interactions that shaped them (Schweiger et al., 2020). Humans have influenced most ecosystems to some degree, through a long history of land-use and management, to the extent that human activities have become intricately intertwined with natural processes and vegetation development (Szabó, 2010). Just as individuals perceive their own personal experience as normal, the reference state for a natural system progressively shifts over consecutive human generations. The practical implications of this case of collective amnesia - what Daniel Pauly called "the shifting baseline syndrome" (Pauly, 1995) - are management strategies and policy decisions that ignore historical states and processes, thus leading to a narrow universe of potential management outcomes and actions. Reconstructing baselines, however challenging, is 

3

\section{4} 5

thus a critical step towards a better understanding of contemporary landscapes and of the realm of possibilities for future management of trees and beyond.

The interplay between humans and the environment over millennia shaped multifaceted socio-ecological systems, making the choice of an appropriate reference point for forest management an arduous task. However, even if former natural processes cannot be completely recovered, decision-makers must be informed about these ecological legacies. Grounding decisions for restoration in a deep-time ecological context will help us better understand the requirements and potentials of extant species (given their deep evolutionary histories), the factors maintaining biodiversity in the long-term, ecological dynamics in the absence of human influence, and the legacies of anthropogenic impact (Svenning, 2020; Swanson et al., 2021). Understanding pre-human reference processes could guide us towards more ambitious restoration objectives and overall promote higher biodiversity and higher resilience to climate change, although it might also conflict with forest management objectives, feasibility and societal acceptance (Svenning 2020, Popejoy et al. 2018). Further, the past is also rich with situated cases from a wide range of socio-ecological contexts and ontological practices related to tree planting and forest management. These form as many empirical examples from which to draw lessons on socio-ecological dynamics, understand drivers of change and explore opportunities for adaptation (Swanson et al., 2021). In box 1, we use one of these examples, the Landes forest in France, to briefly illustrate how a long-term perspective may challenge our perception of what is natural or desirable for tree planting in a particular area.

With this, we do not aim to provide recommendations for which baseline should be used to guide forest management strategies. Ultimately, the choice of a baseline as a target for restoration is a societal decision and should be case specific. But combining natural and social sciences with this historical perspective can be a powerful tool to broaden perspectives for what is possible, help avoid repeating past errors and envision possible futures.

\section{6}

(1) 


\section{Box 1. Shifting baselines and forested landscapes: The Landes forest in France}

In Europe, the reversal from forest decline to expansion alongside urban development creates a useful case study to explore the impact of shifting baselines in contemporary tree planting initiatives. Land claims for agriculture, resulting in widespread deforestation since the Neolithic age, gave way to reforestation in Europe during the middle ages and onwards. These reforestation initiatives focused on restoring exploited areas and changing species composition of forests, e.g. from beech to spruce forests (Evans 2009), primarily for economic purposes. Since two centuries ago, this focus expanded to include afforestation of previously bare lands and coniferous plantation forestry became the norm (Kenk and Guehne, 2001).

The Landes forest in southwestern France illustrates this historical trajectory well. The area was planted with maritime pines Pinus pinaster over thousands of hectares ca. 175 years ago to provide regional economic development, by converting sparsely inhabited agro-pastoral heathlands ('landes' means moor in French) into a forest exploited for wood and pine resin harvesting. This process involved the large-scale drainage of wetlands and resulted in the loss of unique traditional practices (the 'berger des Landes', walking on stilts, is a classical depiction of this lost pastoralist tradition). Today, this area is dominated by dense pine plantations in what has become the biggest artificial forest in Western Europe (ca. 1.2 million hectares) and serves recreational objectives due to its aesthetics and cultural values (Bouisset and Degrémont, 2015), but remains low in biodiversity. Restoring heathlands in this area could thus be seen as a promising strategy to restore ecosystems to their natural state and promote higher biodiversity and resilience to climate change. However, paleo-ecological studies reveal that the heathland does not represent the 'natural' baseline for this system either. Pollen reconstruction suggests that throughout the early Holocene (from ca. 8000 years ago), the landscape was dominated by open woodlands (Faure and Galop, 2011) and that heathland only became dominant towards the middle-ages after several millennia of progressive deforestation initiated at the end of the Neolithic (ca. 5500 years ago). In this context, the choice of one temporal baselines as a reference point for decision-making is challenging and will dramatically affect the realm of possibilities for contemporary forest management (Figure 1). There are benefits and challenges, and certainly limits in what is societally acceptable and ecologically possible, to every scenario. Nonetheless, gaining an understanding of these longterm socio-ecological legacies is critical to determine what is possible and desirable today and in the future. 
Figure 1. Fictional example illustrating the impact of shifting baselines for forest management decisions. The type of data available to reconstruct historical baselines varies as one goes back in time, from ecological surveys and Traditional Ecological Knowledge (TEK) (Huntington, 2000) to historical and industrial (e.g.

Fossil and Pollen record

Historical sources

Molecular data

\subsection{Ecological context: what, where, how to plant?} forestry) sources, fossil and pollen records and molecular data (ancient and modern DNA), illustrating the need for trans-disciplinary approaches to overcome the shifting baseline syndrome.

Following the decision of which is a desirable target for forest restoration, an important starting point is to consider to what extent - if any - trees need to be planted. Natural regeneration can often be effective in restoring forests and woodlands for $\mathrm{NbS}$, helping to promote higher taxonomic and genetic biodiversity (including of native tree species) as well as structural complexity, which is strongly related to biodiversity (Chazdon and Guariguata, 2016). However, some species are limited in their ability for spontaneous regeneration, e.g., due to large seeds adapted for dispersal by now-extinct megafauna, overall rarity or local extirpation due to overuse by humans or lack of processes to facilitate germination. In such cases, it can be relevant to combine natural regeneration with planting. Secondly, old-growth forests sustain unique 
biodiversity (Watson et al., 2018) and are more effective in regulating the climate, e.g. because large trees sequester more carbon than small trees despite lower per unit carbon sequestration efficiency (Musavi et al., 2017; Poorter et al., 2015; Watson et al., 2018). Replacing old growth forest with young, faster-growing trees will always reduce the amount of biospheric carbon stored per unit land area, at least over a 100-200 year period (Körner, 2000; Lewis et al., 2019). Slow-growing trees with longer lifespans will contribute more to carbon storage than fast tree growth followed by harvest and carbon release, as the latter contributes no longterm carbon benefit (Körner, 2017).

Tree-planting initiatives as a NbS for climate change and the biodiversity crisis should focus on areas where co-benefits for carbon storage and biodiversity can be maximized, which requires an understanding of the patterns of environmental and climatic characteristics driving these two critical aspects (Soto-Navarro et al., 2020). Importantly, tree stands with high species richness of mainly native species and high structural heterogeneity are more likely to be resilient to stresses from climate change or introduced tree pests, and will generally have higher productivity (Morin et al., 2011) and biodiversity (Felton et al., 2020). In contrast, species-poor and structurally uniform tree plantations often have negative effects on biodiversity (Bremer and Farley, 2010) and lower carbon sequestration capacities (Li et al., 2019) and in general lower ecosystem services (Gamfeldt et al., 2013). They are also unlikely to be robust to site-specific disturbance regimes and global change stresses. For example, diversity and resilience of above ground carbon stocks within fire-prone natural forests is supported by fire-response traits facilitating fire survival and allowing rapid post-fire regeneration (Clarke et al., 2015; Gordon et al., 2018; Hammill et al., 2016). Therefore, plantations of nonnative trees that have not coevolved with fire, and hence do not possess fire-response traits, are unlikely to provide long-term carbon sequestration gains in fire-prone regions.

Carbon sequestration per unit area of forest depends on climatic processes that impact rates of carbon gain through photosynthesis and carbon loss via plant and microbial respiration (Anderson-Teixeira et al., 2011; Keith et al., 2009; Melillo et al., 2017). Aboveground carbon storage is typically highest in (moist) cooltemperate forests where moderate temperature and precipitation favour plant growth over decomposition (Keith et al., 2009; Liu et al., 2014). Conversely, aboveground carbon sequestration is tempered in cooler boreal forests where low temperatures reduce photosynthesis and plant growth, and tropical forests where warm and wet conditions promote decomposition (Keith et al. 2009; Liu et al. 2014a). Overlapping areas of high carbon storage potential with areas that have high potential for biodiversity conservation in forest ecosystems, makes it possible to identify areas where tree planting could - taking other context variables into account - achieve these joint goals (Soto-Navarro et al. 2020). With growing availability of high-resolution maps of carbon stocks and biodiversity distribution, spatially explicit tree planting planning can increasingly be implemented for the co-benefit of carbon storage and biodiversity (Soto-Navarro et al. 2020). 
Anthropogenic climate change is intensifying and expected to increase pressure on forests over the next decades and beyond, due to drought, heat stress or increased fire risk (Paquette et al. 2018). Therefore, it is important that newly forested areas are resilient to these stresses. Tree species richness is important to buffer against loss of ecosystem productivity and biodiversity from climatic stresses and/or the rising prevalence of introduced tree pests and pathogens (Fichtner et al., 2020; Grossiord, 2019; Grossman et al., 2018; Huang et al., 2018; Jactel et al., 2017). Promoting such resilient ecosystems may be achieved by innovative management strategies such as rewilding (Svenning, 2020), which aims to restore ecological processes that promote selfregulation of ecosystem functions, natural disturbance regimes, and connectivity (Perino et al., 2019). Restoring these factors and processes also ensures that restoration efforts benefit the many species that depend on open- and semi-open habitats (e.g. glades within forests), coarse woody debris and other aspects of ecosystem structure that simple tree planting schemes may overlook (Schweiger and Svenning, 2019).

\subsection{Socio-political context}

The what, where and how of tree planting addressed above interrelate with the socio-political (who and why) and the long-term biogeographical context in which landscapes and ecosystems are formed. Political and historical perspectives also need to be included to set appropriate reference points. From a decision-making perspective for instance, the persuasive end goal of climate change mitigation sometimes outweighs the means to get there, as its power and urgency calls for fast actions to reduce deforestation and enhance carbon uptake in a way that seem to override scientific scrutiny (cf. Berling and Bueger, 2017) and limit a nuanced discussion on exactly where and how to promote trees as carbon sinks.

Under the climate action umbrella, a particular set of economic incentives and mechanisms to protect and plant trees has been on the rise for several decades (Gómez-Baggethun and Ruiz-Pérez, 2011), and provides an example and possible explanation for why more nuanced ecological criteria for promoting trees as a $\mathrm{NbS}$ are not always considered. Initiatives relying on Payment for Ecosystem Services (PES) captures many tree planting and protection programs, such as global climate action projects based on carbon savings from reduced deforestation and enhancement of forest carbon stocks (REDD+). Such PES-like schemes rest on neo-liberal thinking and market-based instruments, illustrating a dominance of (environmental) economists in shaping many large-scale nature conservation programs (Pasgaard et al., 2017). In the slipstream of their dominance, PES-like projects are often criticized for being apolitical and unjust (Fairhead et al., 2012; Milne and Adams, 2012; Van Hecken and Bastiaensen, 2010). Some of this discussion revolves around the geographical location of projects (e.g. Balooni and Lund, 2014) and the actors involved (e.g. Sanders et al., 2017), which are critical when it comes to identifying locations for tree planting and protection. The actual project site selection often depends on what is most feasible and desirable for actors implementing the policies, taking into account their individual agendas and previous engagements rather than ecological criteria (Pasgaard and Mertz, 2016). 
Several studies have shown that climate action initiatives through tropical forest protection not only may overrule democratic considerations in the name of carbon reductions (e.g. Fairhead et al. 2012), but also involve considerable biodiversity trade-offs (Phelps et al., 2012). In other words, the actual promotion of trees as a $\mathrm{NbS}$ tends to be prioritized in places where it fits the branding and existing activities of the climate project investors and implementers (cf. Mosse, 2005; Goldman, 2005) - and not necessarily the 'best suited' locations from an ecological viewpoint in terms of carbon reductions or biodiversity (Pasgaard and Mertz 2016).

\section{Beyond closed forests: valuing other biomes as NbS}

The current narrative of trees and tree planting promotes forest as the ultimate $\mathrm{NbS}$ for environmental and biodiversity challenges (Griscom et al., 2020). However, forest structures contain a gradient of tree cover densities, and open spaces are considered inherent to forests and play important roles in forest biodiversity and vegetation dynamics (Muscolo et al., 2014). Further, while forests harbour the majority of Earth's terrestrial biodiversity (Jones et al., 2018; Kreft and Jetz, 2007), non-forest biomes support unique biodiversity and functions, including carbon sequestration. This section provides a brief ecological background to non-forest biomes, often referred to as open or semi-open vegetation, and will demonstrate why open vegetation plays a key role in global conservation of biodiversity. We also address why open vegetation is not necessarily inferior to closed forest when it comes to sequestering carbon or cooling the Earth system in other ways.

\subsection{History and biodiversity of other biomes}

Open or semi-open vegetation does not imply the complete absence of trees. Rather, it implies an absence of large contiguous areas with closed canopy cover. The naming of biomes or vegetation types with less than $100 \%$ tree cover has been inconsistent, and subject to cultural customs and historical conventions (Higgins et al., 2016; Kumar et al., 2020). Common names include 'forest', 'savanna', 'woodland' and 'shrubland', with or without further qualifiers such as 'open' and 'dense'. However, tree cover alone is not sufficient to categorise landscapes on a forest /non-forest gradient, and other aspects of vegetation structure and plant traits need to be considered, especially the presence and abundance of grasses. For example, in the (sub-)tropics the presence of a more-or-less continuous cover of $\mathrm{C}_{4}$ grasses is a reliable indicator that the vegetation is not a forest, even if tree canopy cover is $>80 \%$ (Ratnam et al., 2011).

$\mathrm{C}_{4}$ grasslands spread globally during the late Miocene and Pliocene (3 to $8 \mathrm{Ma}$ ) and were accompanied by a surge in grass-fuelled fires, especially in the seasonally dry subtropics, i.e. today's vast savannahs of Africa, South America, India and Australia (Bond and Keeley, 2005; Lehmann et al., 2011). These novel grassy and flammable environments triggered adaptations and diversification in other taxa, including a spectacular diversification of the bovid family, including bison, gazelles, wildebeest, and sheep (Charles-Dominique et al., 
2016). Dominant tree species in open grassy vegetation typically have adaptations to resist, avoid or cope with fire and large mammal herbivores, the two main consumers of live plant biomass (Bond \& Keeley 2005). Tropical and subtropical savannahs, especially in Africa where a largely grass-dependent megafauna has mostly escaped the late-Quaternary extinction wave, clearly illustrate the unique biodiversity that would be lost if trees were planted without considering the ecological context. Many other taxa demonstrate the significance of non-forest vegetation in driving diversification and supporting non-forest biodiversity, also in non-forest ecosystems without $\mathrm{C}_{4}$ grasses. For example, the falcon family (Falconidae) diversified rapidly with the Miocene expansion of $\mathrm{C}_{4}$-grasslands (Fuchs et al., 2015) and the majority of European butterflies depend on open ecosystems or semi-open spaces within woodlands (Streitberger et al., 2012; van Swaay et al., 2006). The seeds or seed capsules in Mediterranean shrublands such as the Fynbos require exposure to fire and/or smoke to open and germinate; a clear indication of a long fire history, which is incompatible with closedcanopy forest (Lamont et al., 1991; Rundel et al., 2016). In summary, non-forest ecosystems have produced and continue to maintain taxa that are fundamentally incompatible with closed-canopy forests. We discuss below how these ecosystems play an important role in climate regulation through carbon sequestration and other radiative forcings.

\subsection{Climate regulation by other types of ecosystems}

\section{Carbon sequestration}

As grasses and savannah trees have less (woody) biomass than typical forest trees, they store less above-ground carbon per unit area per unit time than a typical closed forest. However, like closed forests, savanna ecosystems also sequester and store carbon, notably below-ground. As such, they are a major contributor to global carbon dynamics and Earth's energy balance (Poulter et al., 2014). Furthermore, recent studies show that soil carbon storage in tropical savannahs is higher in savannahs with fewer woody plants, suggesting that grasses are more effective at storing carbon below ground in the absence of trees (Wigley et al., 2020). Importantly, areas with fewer trees were maintained in that state by native wild herbivores, underlining the importance of ecosystem processes. Similarly, flammable temperate savannahs may have more soil carbon than nearby forests that do not burn (Pellegrini et al., 2020). Ecosystems that are not forest nor grassy are also important for the global energy budget. For example, tundra and associated permafrost are the largest soil carbon sink globally, accounting for approximately 50\% of all soil carbon stocks (Tarnocai et al., 2009). Wetlands including peat bogs cover 5-8\% of the terrestrial land surface but store 20-30\% of Earth's soil carbon (Dargie et al., 2017), even when methane emissions are considered (Mitsch et al., 2013). As for grassy ecosystems, disturbance regulates soil carbon sequestration in both tundra and wetland ecosystems. For example, large herbivore grazing moderates climate-mediated carbon losses in tundra (Ylänne et al., 2020). 
533 In addition to sequestering and storing carbon, vegetation can warm up or cool down the Earth's surface in 534 other ways. The first important mechanism is the reflectivity to sunlight, albedo: the higher the reflectivity of 535 a type of vegetation, the less heat is absorbed. The albedo is higher for savannah grasses (grey-green) than e.g. 536 tropical forests (dark green) (Bonan, 2016, 2008). Furthermore, most commercial forestry species suitable for 537 semi-arid climates are evergreen (e.g. pines), which means that additional heat gets absorbed during the dry 538 season, when native vegetation tends to be bare or brown (high albedo). This overall higher heat reflection of 539 grassy ecosystems compared to forests helps cool the Earth surface (Bonan, 2016; Lee et al., 2011). Secondly, 540 all plants transpire water into the atmosphere through small pores in the leaf (stomata). Water vapour is also a 541 powerful greenhouse gas and planting trees will thus increase the amount of water vapour in the atmosphere 542 (Swann et al., 2010) as woody vegetation contributes more to evapotranspiration than grasses (Yepez et al., 543 2003). Besides the carbon storage qualities of trees, forest could consequently increase local temperatures and 544 have unintended side effects on climate warming (Baldocchi and Penuelas, 2019; Rotenberg and Yakir, 2010). 545 The role of trees and other vegetation in climate warming is therefore not one-dimensional, and we need to 546 increase efforts to understand key processes that regulate the climate impacts of closed forest and non-forest 547 ecosystems, including albedo and effects of surface roughness on energy exchange (Bonan 2016). 
The aim of this paper is not to object to the promotion of trees. Instead, we aim to explore the origins of tree promotion as the panacea for $\mathrm{NbS}$ and to provide alternatives and complementary strategies. To do so, we provided an overview of historical social and ecological factors that need to be considered in order for the promotion of trees to have the desired effects, e.g. mitigate the biodiversity and climate crises. Our main argument is that tree planting has become a generalizable 'technical' NbS to address climate change, which overlooks regional contexts and other potential solutions. Without arguing against tree planting or promotion per se, its simplified dominance calls for a nuanced approach to global environmental challenges by exploring the limitations and oversights of tree-centered solutions, within appropriate ecological and socioeconomic contexts

Tree planting is an attractive solution to environmental issues because it is straightforward and has a shared positive symbolic connotation. The simplistic discourse around tree planting is co-created by the historical meaning of trees, the shift in stakeholders and perspectives involved in tree planting towards environmentalism and the framing of environmental issues as technological challenges or as wicked problems of governance. However, this simplistic framing distances the causes and solutions of environmental issues away from individual, corporate, and regulatory governance responsibilities. Our remote sensing-based examples indicate that the representation of trees in global forest modelling potentially reinforces an overly simplistic definition of trees and forest (section 2.4). The implications of these simplifications influence decision-making processes concerning tree promoting initiatives (section 3.3 and Chapter 2). In order to reflect on the potential of rethinking the current tree planting discourse and be receptive to a more inclusive and diverse perspective on $\mathrm{NbS}$, we therefore need to remain critical of accepted methodologies and be mindful of their limitations. Although global forest models have built an important basis for globally monitoring forest-cover changes, the global image they provide only partially reflects on-the-ground complexities, and therefore should not be used as a standalone authority. The recent arrival of high-resolution satellite data provides diverse coverage and new opportunities to create more nuanced observations that model forests as a global object.

Despite the victory of international policy and financial commitments to promote tree planting as a way to address human induced climate issues and the loss of biodiversity, tree planting is not the global panacea. $\mathrm{Di}$ Sacco et al. recently gathered evidence from the most recent ecological research to propose ten golden rules to support the delivery of forest restoration approaches that maximizes rates of both carbon sequestration and biodiversity recovery while improving livelihoods (Di Sacco et al., 2021). They argue for forest restoration initiatives to be "based on sound science, guided by indigenous knowledge and local communities, supported by fair governance, and incentivized by long-term funding mechanisms". Our paper supports this nuanced narrative, as we notably argue that tree planting and promotion needs to reflect and be in sync with the social 
and ecological context (Figure 2). More specific ecological criteria regarding which species, and where, how and who to promote trees need to be further taken into account in tree promotion initiatives. Yet, we do not argue to rely on ecological criteria alone, as this would be both unrealistic and undesirable. By selecting areas for tree planting or protection based solely on ecological or climatic criteria, we might risk yet another case of 'green grabbing' when those with political power dispossess local communities from their rights (Fairhead et al. 2012). Instead, we strongly argue to always include both ecological and socio-ecological knowledge alongside political and economic considerations, in order to nuance decisions about the selection of species and locations for tree planting or protection (Swanson et al., 2021).

Other NbS should also not be excluded from the dialogue. Our discussion in Chapter 3 illustrates three important points: 1) More trees, or greater tree cover replacing open vegetation, does not necessarily mean more carbon sequestration, 2) Disturbances such as fire and herbivores that remove above-ground biomass can increase carbon sequestration relative to undisturbed forests, and 3) Tree planting does not necessarily generate a higher (local) reduction in temperature compared to other types of vegetation. Collectively, these examples highlight that non- (closed) forested ecosystems across a diverse range of landscapes and biomes are crucial in regulating Earth's carbon budget.

Fundamentally, tree planting should aim beyond mere carbon sequestration for climate regulation and focus on socially just initiatives generating biodiverse, self-regulating ecosystems resilient to global change stresses and that consider biodiversity holistically, beyond trees (Veldman et al. 2015; Brancalion \& Chazdon 2017). Priority should also be given to other climate solutions such as reduction of fossil fuels and avoiding deforestation (Grantham et al., 2020) and the potential for other natural carbon storage ecosystems, such as wetlands and peatlands, should not be overshadowed by discussions on tree planting. In policies and interventions, NbS should be nuanced by unfolding the context (what, where, how, who) and by embracing and valuing other vegetation types in addition to forests as $\mathrm{NbS}$, and these alternatives must of course also be applied in a context-sensitive manner. Aiming for these ambitious objectives is the way forward to avoid creating unstable systems with ultimately limited or zero benefits for biodiversity and climate, and thereby human societies.

(1)
(1) 


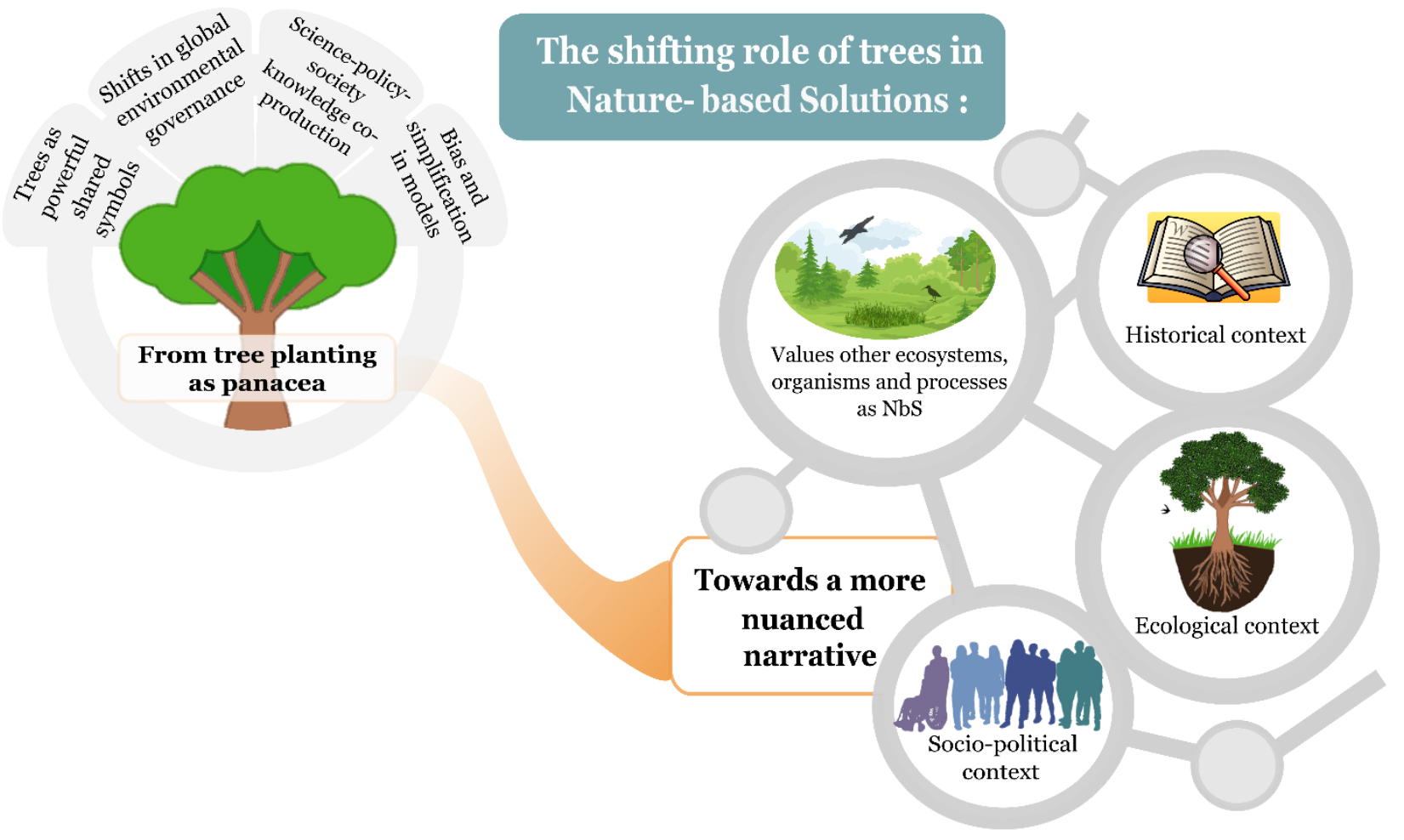

614 Figure 2. Schematic diagram of the road from tree planting as a panacea narrative (left panel) towards a 615 more nuanced narrative, rooted in the historical, ecological and social-political context (right panel), which 616 values other ecosystems as nature-based solutions (NbS) and also protects non-closed forest ecosystems and 617 biodiversity. In order to support this shift, we deconstructed the historical and power dynamics that played a 618 role in the construction and maintenance of this panacea framework. The power of shared symbolism, shifts 619 in environmental governance, science-policy-public knowledge and policy co-production and the biases and 620 simplifications required to construct models to study forest ecosystems need to be acknowledged as part of the 621 'problem' and 'solution' to obtaining a nuanced perspective on tree planting.

\section{Acknowledgments}

This work is a contribution to the Carlsberg Foundation Semper Ardens project MegaPast2Future (grant no. CF16-0005 to J.-C.S.), to the VILLUM Investigator project 'Biodiversity Dynamics in a Changing World' funded by VILLUM FONDEN (grant no. 16549 to J.-C.S.) and to TerraNova - The European Landscape Learning Initiative: Past and Future Environments and Energy Regimes shaping Policy Tools (grant 813904) funded by the European Commission. 
Agnoletti, M., Anderson, S. (eds.) 2000. Methods and approaches in forest history. CABI, Wallingford, United Kingdom.

Anderson-Teixeira, K.J., Delong, J.P., Fox, A.M., Brese, D.A., Litvak, M.E., 2011. Differential responses of production and respiration to temperature and moisture drive the carbon balance across a climatic gradient in New Mexico. Glob. Chang. Biol. 17, 410-424. https://doi.org/10.1111/j.13652486.2010.02269.x

Aykut, S. C., Foyer, J., \& Morena, E. (Eds.). 2017. Globalising the climate: Cop21 and the climatisation of global debates. Taylor \& Francis, London and New York.

Bäckstrand, K., Lövbrand, E., 2006. Planting trees to mitigate climate change: contested discourses of ecological modernization, green governmentality and civic environmentalism. Glob. Environ. Polit. 6, 50-75. https://doi.org/10.1162/152638006775991911

Baldocchi, D., Penuelas, J., 2019. The physics and ecology of mining carbon dioxide from the atmosphere by ecosystems. Glob. Chang. Biol. 25, 1191-1197. https://doi.org/10.1111/gcb.14559

Balooni, K., Lund, J.F., 2014. Forest rights: The hard currency of REDD+. Conserv. Lett. 7, $278-284$. https://doi.org/10.1111/conl.12067

Bastin, J.-F., Finegold, Y., Garcia, C., Mollicone, D., Rezende, M., Routh, D., Zohner, C.M., Crowther, T.W., 2019. The global tree restoration potential. Science (80-. ). 366, 76-79. https://doi.org/10.1126/science.aay8060

Becken, S., 2004. How tourists and tourism experts perceive climate change and carbon-offsetting schemes. J. Sustain. Tour. 12, 332-345. https://doi.org/10.1080/09669580408667241

Bennett, J. (2010). Vibrant matter: A political ecology of things. Duke University Press, Durham.

Berling, T.V., Bueger, C., 2017. Expertise in the age of post-factual politics: An outline of reflexive strategies. Geoforum 84, 332-341. https://doi.org/10.1016/j.geoforum.2017.05.008

Bonan, G.B., 2016. Forests, climate, and public policy: A 500-Year interdisciplinary odyssey. Annu. Rev. Ecol. Evol. Syst. 47, 97-121. https://doi.org/10.1146/annurev-ecolsys-121415-032359

Bonan, G.B., 2008. Forests and climate change: Forcings, feedbacks, and the climate benefits of forests. Science (80-. ). 320, 1444-1449. https://doi.org/10.1126/science.1155121

Bond, W.J., Keeley, J.E., 2005. Fire as a global "herbivore": The ecology and evolution of flammable ecosystems. Trends Ecol. Evol. 20, 387-394. https://doi.org/10.1016/j.tree.2005.04.025

Bond, W.J., Stevens, N., Midgley, G.F., Lehmann, C.E.R., 2019. The Trouble with Trees: Afforestation Plans for Africa. Trends Ecol. Evol. 34, 963-965. https://doi.org/10.1016/j.tree.2019.08.003

Bouisset, C., Degrémont, I., 2015. From communication to public perceptions: diversity of roles and values in a planted forest. The case of the Landes of Gascony (France), in: Xiv World Forestry Congress. Durban, South Africa.

Bremer, L.L., Farley, K.A., 2010. Does plantation forestry restore biodiversity or create green deserts? A synthesis of the effects of land-use transitions on plant species richness. Biodivers. Conserv. 19, 38933915. https://doi.org/10.1007/s10531-010-9936-4

Buijs, A.E., 2009. Lay people's images of nature: Comprehensive frameworks of values, beliefs, and value orientations. Soc. Nat. Resour. 22, 417-432. https://doi.org/10.1080/08941920801901335

Cao, S., Xu, C., Chen, L., Wang, X., 2009. Attitudes of farmers in China's northern Shaanxi Province 
towards the land-use changes required under the Grain for Green Project, and implications for the project's success. Land use policy 26, 1182-1194. https://doi.org/10.1016/j.landusepol.2009.02.006

Cernea, M.M., 1992. A Sociological Framework: Policy, Environment, and the Social Actors for Tree Planting, in: World Bank Reprint Series. pp. 301-335.

Charles-Dominique, T., Davies, T.J., Hempson, G.P., Bezeng, B.S., Daru, B.H., Kabongo, R.M., Maurin, O., Muasya, A.M., Van Der Bank, M., Bond, W.J., 2016. Spiny plants, mammal browsers, and the origin of African savannas. Proc. Natl. Acad. Sci. U. S. A. 113, E5572-E5579. https://doi.org/10.1073/pnas.1607493113

Chazdon, R.L., Guariguata, M.R., 2016. Natural regeneration as a tool for large-scale forest restoration in the tropics: prospects and challenges. Biotropica 48, 716-730. https://doi.org/10.1111/btp.12381

Chiarucci, A., Piovesan, G., 2020. Need for a global map of forest naturalness for a sustainable future. Conserv. Biol. 34, 368-372. https://doi.org/10.1111/cobi.13408

Clarke, P.J., Lawes, M.J., Murphy, B.P., Russell-Smith, J., Nano, C.E.M., Bradstock, R., Enright, N.J., Fontaine, J.B., Gosper, C.R., Radford, I., Midgley, J.J., Gunton, R.M., 2015. A synthesis of postfire recovery traits of woody plants in Australian ecosystems. Sci. Total Environ. 534, 31-42. https://doi.org/10.1016/j.scitotenv.2015.04.002

Cohen, A.P., 1985. Symbolic construction of community. Taylor \& Francis Group.

Dargie, G.C., Lewis, S.L., Lawson, I.T., Mitchard, E.T.A., Page, S.E., Bocko, Y.E., Ifo, S.A., 2017. Age, extent and carbon storage of the central Congo Basin peatland complex. Nature 542, 86-90. https://doi.org/10.1038/nature21048

Davis, D.K., Robbins, P., 2018. Ecologies of the colonial present: Pathological forestry from the taux de boisement to civilized plantations . Environ. Plan. E Nat. Sp. 1, 447-469. https://doi.org/10.1177/2514848618812029

Devine, J.A., Baca, J.A., 2020. The Political Forest in the Era of Green Neoliberalism. Antipode 52, 911927. https://doi.org/10.1111/anti.12624

Dewulf, A., 2013. Contrasting frames in policy debates on climate change adaptation. WIREs Clim. Chang. 4, 321-330. https://doi.org/10.1002/wcc.227

Di Sacco, A., Breman, E., Elliott, S., Smith, R.J., Hardwick, K.A., Blakesley, D., Brancalion, P.H.S., Rebola, L.C., Chomba, S., Dixon, K., Ruyonga, G., Shaw, K., Smith, P., 2021. Ten golden rules for reforestation to optimize carbon sequestration, biodiversity recovery and livelihood benefits. Glob. Chang. Biol. 1-21. https://doi.org/10.1111/gcb.15498

Edwards, P.N. 2010. A vast machine: Computer models, climate data, and the politics of global warming. MIT Press, Cambridge, Mass.

Edwards, P. 2000. "The World in a Machine: Origins and Impacts of Early Computerized Global Systems Models", in: Systems, Experts, and Computers: The Systems Approach in Management and Engineering, World War II and After, Agatha C. Hughes, Thomas Parke Hughes 10.7551/mitpress/6607.003.0009

Enuoh, O.O.O., Bisong, F.E., 2015. Colonial forest policies and tropical deforestation: the case of Cross River State, Nigeria. Open J. For. 05, 66-79. https://doi.org/10.4236/ojf.2015.51008

Etongo, D., Djenontin, I.N.S., Kanninen, M., Fobissie, K., 2015. Smallholders' tree planting activity in the Ziro province, southern Burkina Faso: Impacts on livelihood and policy implications. Forests 6, 26552677. https://doi.org/10.3390/f6082655 
European Commission, 2020. Communication from the Commission to the European Parliament, the Council, the European Economic and Social Committee and the Committee of the Regions, EU Biodiversity Strategy for 2030, European Commission, EU Biodiversity Strategy for 2030 - Bringing nature back into our lives. Brussels.

Evans, J., 2009. Planted Forests - Uses, Impacts \& Sustainability. Food and Agriculture Organisation of the United Nations.

Fairhead, J., Leach, M., Scoones, I., 2012. Green Grabbing: A new appropriation of nature? J. Peasant Stud. 39, 237-261. https://doi.org/10.1080/03066150.2012.671770

Faruqi, S., Wu, A., Brolis, E., Anchondo Ortega, A., Batista, A., 2018. The business of planting trees - A growing investment opportunity. World Resources Institute and The Nature Conservancy. https://doi.org/10.3732/ajb.1700332

Faure, E., Galop, D., 2011. La fin du paradigme du désert landais : histoire de la végétation et de 1' anthropisation à partir de 1' étude palynologique de quelques lagunes de la Grande-Lande. Aquitania, Pessac: Fédération Aquitania.

Felton, A., Petersson, L., Nilsson, O., Witzell, J., Cleary, M., Felton, A.M., Björkman, C., Sang, Å.O., Jonsell, M., Holmström, E., Nilsson, U., Rönnberg, J., Kalén, C., Lindbladh, M., 2020. The tree species matters: Biodiversity and ecosystem service implications of replacing Scots pine production stands with Norway spruce. Ambio 49, 1035-1049. https://doi.org/10.1007/s13280-019-01259-x

Fernow, B.E. 1911. History of forestry. Forestry Quarterly, Toronto, Canada.

Fichtner, A., Schnabel, F., Bruelheide, H., Kunz, M., Mausolf, K., Schuldt, A., Härdtle, W., von Oheimb, G., 2020. Neighbourhood diversity mitigates drought impacts on tree growth. J. Ecol. 108, 865-875. https://doi.org/10.1111/1365-2745.13353

Fine, G. A. (2007). Authors of the storm: Meteorologists and the culture of prediction. University of Chicago Press, Chicago.

Friedlingstein, P., Allen, M., Canadell, J.G., Peters, G.P., Seneviratne, S.I., 2019. Comment on "The global tree restoration potential." Science (80-. ). 366, eaaz0388. https://doi.org/10.1890/090179

Fuchs, J., Johnson, J.A., Mindell, D.P., 2015. Rapid diversification of falcons (Aves: Falconidae) due to expansion of open habitats in the Late Miocene. Mol. Phylogenet. Evol. 82, 166-182. https://doi.org/10.1016/j.ympev.2014.08.010

Gamfeldt, L., Snäll, T., Bagchi, R., Jonsson, M., Gustafsson, L., Kjellander, P., Ruiz-Jaen, M.C., Fröberg, M., Stendahl, J., Philipson, C.D., Mikusiński, G., Andersson, E., Westerlund, B., Andrén, H., Moberg, F., Moen, J., Bengtsson, J., 2013. Higher levels of multiple ecosystem services are found in forests with more tree species. Nat. Commun. 4. https://doi.org/10.1038/ncomms2328

Goldman, M. 2005. Imperial Nature: The World Bank and Struggles for Social Justice in the Age of Globalization. Yale University Press, New Haven, Connetticut.

Gómez-Baggethun, E., Ruiz-Pérez, M., 2011. Economic valuation and the commodification of ecosystem services. Prog. Phys. Geogr. 35, 613-628. https://doi.org/10.1177/0309133311421708

Gordon, C.E., Bendall, E.R., Stares, M.G., Collins, L., Bradstock, R.A., 2018. Aboveground carbon sequestration in dry temperate forests varies with climate not fire regime. Glob. Chang. Biol. 24, 42804292. https://doi.org/10.1111/gcb.14308

Grantham, H.S., Duncan, A., Evans, T.D., Jones, K., Beyer, H., Schuster, R., Walston, J., Ray, J., Robinson, J., Callow, M., Clements, T., Costa, H.M., DeGemmis, A., Elsen, P.R., Ervin, J., Franco, P., Goldman, E., Goetz, S., Hansen, A., Hofsvang, E., Jantz, P., Jupiter, S., Kang, A., Langhammer, P., Laurance, 
W.F., Lieberman, S., Linkie, M., Malhi, Y., Maxwell, S., Mendez, M., Mittermeier, R., Murray, N., Possingham, H., Radachowsky, J., Samper, C., Silverman, J., Shapiro, A., Strassburg, B., Stevens, T., Stokes, E., Taylor, R., Tear, T., Tizard, R., Venter, O., Visconti, P., Wang, S., Watson, J.E.M., 2020. Modification of forests by people means only $40 \%$ of remaining forests have high ecosystem integrity. bioRxiv 2020.03.05.978858. https://doi.org/10.1101/2020.03.05.978858

Griffith, D.M., Lehmann, C.E.R., Strömberg, C.A.E., Parr, C.L., Pennington, R.T., Sankaran, M., Ratnam, J., Still, C.J., Powell, R.L., Hanan, N.P., Nippert, J.B., Osborne, C.P., Good, S.P., Anderson, T.M., Holdo, R.M., Veldman, J.W., Durigan, G., Tomlinson, K.W., Hoffmann, W.A., Archibald, S., Bond, W.J., 2017. Comment on "The extent of forest in dryland biomes." Science (80-. ). 358, 27-30. https://doi.org/10.1126/science.aao1309

Griscom, B., Jackson, R.B., Konijnendijk, C., Luyssaert, S., Friess, D., Rudee, A., Seddon, N., 2020. Trees as Nature-Based Solutions. One Earth 2, 387-389. https://doi.org/10.1016/j.oneear.2020.04.016

Grossiord, C., 2019. Having the right neighbors: how tree species diversity modulates drought impacts on forests. New Phytol. 228. https://doi.org/10.1111/nph.15667

Grossman, J.J., Vanhellemont, M., Barsoum, N., Bauhus, J., Bruelheide, H., Castagneyrol, B., CavenderBares, J., Eisenhauer, N., Ferlian, O., Gravel, D., Hector, A., Jactel, H., Kreft, H., Mereu, S., Messier, C., Muys, B., Nock, C., Paquette, A., Parker, J., Perring, M.P., Ponette, Q., Reich, P.B., Schuldt, A., Staab, M., Weih, M., Zemp, D.C., Scherer-Lorenzen, M., Verheyen, K., 2018. Synthesis and future research directions linking tree diversity to growth, survival, and damage in a global network of tree diversity experiments. Environ. Exp. Bot. 152, 68-89. https://doi.org/10.1016/j.envexpbot.2017.12.015

Hammill, K., Penman, T., Bradstock, R., 2016. Responses of resilience traits to gradients of temperature, rainfall and fire frequency in fire-prone, Australian forests: potential consequences of climate change. Plant Ecol. 217, 725-741. https://doi.org/10.1007/s11258-016-0578-9

Hansen, M.C., Potapov, P., Moore, R., Hancher, M., Turubanova, S., Tyukavina, A., Thau, D., Stehman, S., Goetz, S., Loveland, T., Kommareddy, A., Egorov, A., Chini, L., Justice, C.O., Townshend, J., 2013. High-resolution global maps of 21st-century forest cover change. Science (80-. ). 354, 850-853. https://doi.org/10.1126/science. 1244693

Hastrup, K., Skrydstrup, M. (Eds.) 2013. The Social Life of Climate Change Models: Anticipating Nature, Routledge, Abingdon-on-Thames, United Kingdom.

Hauer, R.J., Miller, R.W., Werner, L.P., 2008. The history of trees in the city, Handbook of Urban Forestry.

Higgins, S.I., Buitenwerf, R., Moncrieff, G.R., 2016. Defining functional biomes and monitoring their change globally. Glob. Chang. Biol. 22, 3583-3593. https://doi.org/10.1111/gcb.13367

Holl, K.D., Brancalion, P.H.S., 2020. Tree planting is not a simple solution. Science (80-. ). 368, $580-581$. https://doi.org/10.1126/science.aba8232

Huang, Y., Chen, Y., Castro-Izaguirre, N., Baruffol, M., Brezzi, M., Lang, A., Li, Y., Härdtle, W., Oheimb, G. von, Yang, X., Liu, X., Pei, K., Both, S., Yang, B., Eichenberg, D., Assmann, T., Bauhus, J., Behrens, T., Buscot, F., Chen, X.-Y., Chesters, D., Ding, B.-Y., Durka, W., Erfmeier, A., Fang, J., Fischer, M., Guo, L.-D., Guo, D., Gutknecht, J.L.M., He, J.-S., He, C.-L., AndyHector, Hönig, L., RenYongHu, Klein, A.-M., Kühn, P., YuLiang, Li, S., Michalski, S., Scherer-Lorenzen, M., Schmidt, K., Scholten, T., Schuldt, A., XuezhengShi, Tan, M.-Z., Tang, Z., Trogisch, S., Wang, Z., Welk, E., Wirth, C., Wubet, T., Xiang, W., Yu, M., Yu, X.-D., Zhang, J., Zhang, S., Zhang, N., Hong-ZhangZhou, Zhu, C.-D., Zhu, L., Bruelheide, H., Ma, K., Niklaus, P.A., Schmid, B., 2018. Impacts of species richness on productivity in a large-scale subtropical forest experiment. Science (80-. ). 362, 80-83. https://doi.org/10.1126/science.aav9117

Hulme, M. 2013. How Climate Models Gain and Exercise Authority. The Social Life of Climate Change 
Hume C. 2015. Negotiating Partners: Friends or Foes?. In: Galluccio M. (eds) Handbook of International Negotiation. Springer, Cham. https://doi.org/10.1007/978-3-319-10687-8_26

Huntington, H.P., 2000. Using traditional ecological knowledge in science: Methods and applications. Ecol. Appl. 10, 1270-1274. https://doi.org/10.1890/1051-0761(2000)010[1270:UTEKIS]2.0.CO;2

Jactel, H., Bauhus, J., Boberg, J., Bonal, D., Castagneyrol, B., Gardiner, B., Gonzalez-Olabarria, J.R., Koricheva, J., Meurisse, N., Brockerhoff, E.G., 2017. Tree diversity drives forest stand resistance to natural disturbances. Curr. For. Reports 3, 223-243. https://doi.org/10.1007/s40725-017-0064-1

Jones, K.R., Venter, O., Fuller, R.A., Allan, J.R., Maxwell, S.L., Negret, P.J., Watson, J.E.M., 2018. Onethird of global protected land is under intense human pressure. Science (80-. ). 360, 788-791. https://doi.org/10.1126/science.aap9565

Keesstra, S., Nunes, J., Novara, A., Finger, D., Avelar, D., Kalantari, Z., Cerdà, A., 2018. The superior effect of nature based solutions in land management for enhancing ecosystem services. Sci. Total Environ. 610-611, 997-1009. https://doi.org/10.1016/j.scitotenv.2017.08.077

Keith, H., Mackey, B.G., Lindenmayer, D.B., 2009. Re-evaluation of forest biomass carbon stocks and lessons from the world's most carbon-dense forests. Proc. Natl. Acad. Sci. U. S. A. 106, 11635-11640. https://doi.org/10.1073/pnas.0901970106

Kenk, G., Guehne, S., 2001. Management of transformation in central Europe. For. Ecol. Manage. 151, 107119. https://doi.org/10.1016/S0378-1127(00)00701-5

Keulartz, J., Van Der Windt, H., Swart, J., 2004. Concepts of nature as communicative devices: The case of Dutch nature policy. Environ. Values 13, 81-99. https://doi.org/10.3197/096327104772444785

Konijnendijk, C.C., 2017. The forest and the city - The Cultural Landscape of Urban Woodland. Springer. https://doi.org/10.1017/9781139015257.007

Konijnendijk, C.C., 2008. The Forest and the City. Springer. https://doi.org/10.1007/978-1-4020-8371-6

Körner, C., 2017. A matter of tree longevity. Science (80-. ). 355, 130-131. https://doi.org/10.1126/science.aal2449

Körner, C., 2000. Biosphere responses to CO2 enrichment. Ecol. Appl. 10, 1590-1619. https://doi.org/10.2307/2641226

Kreft, H., Jetz, W., 2007. Global patterns and determinants of vascular plant diversity. Proc. Natl. Acad. Sci. U. S. A. $104,5925-5930$.

Kumar, D., Pfeiffer, M., Gaillard, C., Langan, L., Martens, C., Scheiter, S., 2020. Misinterpretation of Asian savannas as degraded forest can mislead management and conservation policy under climate change. Biol. Conserv. 241, 108293. https://doi.org/10.1016/j.biocon.2019.108293

Lamont, B.B., Le Maitre, D.C., Cowling, R.M., Enright, N.J., 1991. Canopy seed storage in woody plants. Bot. Rev. 57, 277-317. https://doi.org/10.1007/BF02858770

Lee, X., Goulden, M.L., Hollinger, D.Y., Barr, A., Black, T.A., Bohrer, G., Bracho, R., Drake, B., Goldstein, A., Gu, L., Katul, G., Kolb, T., Law, B.E., Margolis, H., Meyers, T., Monson, R., Munger, W., Oren, R., Paw U, K.T., Richardson, A.D., Schmid, H.P., Staebler, R., Wofsy, S., Zhao, L., 2011. Observed increase in local cooling effect of deforestation at higher latitudes. Nature 479, 384-387. https://doi.org/10.1038/nature10588

Lehmann, C.E.R., Archibald, S.A., Hoffmann, W.A., Bond, W.J., 2011. Deciphering the distribution of the savanna biome. New Phytol. 191, 197-209. https://doi.org/10.1111/j.1469-8137.2011.03689.x 
Lewis, S.L., Wheeler, C.E., Mitchard, E.T.A., Koch, A., 2019. Restoring natural forests is the best way to remove atmospheric carbon. Nature 568, 25-28. https://doi.org/10.1038/d41586-019-01026-8

Li, T.M., 2007. Practices of assemblage and community forest management. Econ. Soc. 36, 263-293. https://doi.org/10.1080/03085140701254308

Li, Y., Bruelheide, H., Scholten, T., Schmid, B., Sun, Z., Zhang, N., Bu, W., Liu, X., Ma, K., 2019. Early positive effects of tree species richness on soil organic carbon accumulation in a large-scale forest biodiversity experiment. J. Plant Ecol. 12, 882-893. https://doi.org/10.1093/jpe/rtz026

Liu, Y., Yu, G., Wang, Q., Zhang, Y., 2014. How temperature, precipitation and stand age control the biomass carbon density of global mature forests. Glob. Ecol. Biogeogr. 23, 323-333. https://doi.org/10.1111/geb.12113

Lövbrand, E., 2007. Pure science or policy involvement? Ambiguous boundary-work for Swedish carbon cycle science. Environ. Sci. Policy 10, 39-47. https://doi.org/10.1016/j.envsci.2006.10.003

Lund, J.F., 2015. Paradoxes of participation: The logic of professionalization in participatory forestry. For. Policy Econ. 60, 1-6. https://doi.org/10.1016/j.forpol.2015.07.009

Melillo, J.M., Frey, S.D., DeAngelis, K.M., Werner, W.J., Bernard, M.J., Bowles, F.P., Pold, G., Knorr, M.A., Grandy, A.S., 2017. Long-term pattern and magnitude of soil carbon feedback to the climate system in a warming world. Science (80-. ). 358, 101-105. https://doi.org/10.1126/science.aan2874

Mihoub, J.B., Henle, K., Titeux, N., Brotons, L., Brummitt, N.A., Schmeller, D.S., 2017. Setting temporal baselines for biodiversity: The limits of available monitoring data for capturing the full impact of anthropogenic pressures. Sci. Rep. 7, 41591. https://doi.org/10.1038/srep41591

Milne, S., Adams, B., 2012. Market Masquerades: Uncovering the Politics of Community-level Payments for Environmental Services in Cambodia. Dev. Change 43, 133-158. https://doi.org/10.1111/j.14677660.2011.01748.x

Mitsch, W.J., Bernal, B., Nahlik, A.M., Mander, Ü., Zhang, L., Anderson, C.J., Jørgensen, S.E., Brix, H., 2013. Wetlands, carbon, and climate change. Landsc. Ecol. 28, 583-597. https://doi.org/10.1007/s10980-012-9758-8

Morin, X., Fahse, L., Scherer-Lorenzen, M., Bugmann, H., 2011. Tree species richness promotes productivity in temperate forests through strong complementarity between species. Ecol. Lett. 14, 1211-1219. https://doi.org/10.1111/j.1461-0248.2011.01691.x

Mosse, David. 2005. Cultivating Development: An Ethnography of Aid Policy and Practice : Pluto Press, London, United Kingdom.

Musavi, T., Migliavacca, M., Reichstein, M., Kattge, J., Wirth, C., Black, T.A., Janssens, I., Knohl, A., Loustau, D., Roupsard, O., Varlagin, A., Rambal, S., Cescatti, A., Gianelle, D., Kondo, H., Tamrakar, R., Mahecha, M.D., 2017. Stand age and species richness dampen interannual variation of ecosystemlevel photosynthetic capacity. Nat. Ecol. Evol. 1, 1-6. https://doi.org/10.1038/s41559-016-0048

Muscolo, A., Bagnato, S., Sidari, M., Mercurio, R., 2014. A review of the roles of forest canopy gaps. J. For. Res. 25, 725-736. https://doi.org/10.1007/s11676-014-0521-7

Newton, P., Oldekop, J.A., Brodnig, G., Karna, B.K., Agrawal, A., 2016. Carbon, biodiversity, and livelihoods in forest commons: synergies, trade-offs, and implications for REDD+. Environ. Res. Lett. 11, 114022. https://doi.org/10.1088/1748-9326/11/4/044017

Osmond, D.L., Nadkarni, N.M., Driscoll, C.T., Andrews, E., Gold, A.J., Broussard Allred, S.R., Berkowitz, A.R., Klemens, M.W., Loecke, T.L., Ann McGarry, M., Schwarz, K., Washington, M.L., Groffman, P.M., 2010. The role of interface organizations in science communication and understanding. Front. 
Pasgaard, M., Mertz, O., 2016. Desirable qualities of REDD+ projects not considered in decisions of project locations. Environ. Res. Lett. 11, 114014. https://doi.org/10.1088/1748-9326/11/11/114014

Pasgaard, M., Van Hecken, G., Ehammer, A., Strange, N., 2017. Unfolding scientific expertise and security in the changing governance of Ecosystem Services. Geoforum 84, 354-367. https://doi.org/10.1016/j.geoforum.2017.02.001

Pauly, D., 1995. Anecdotes of the shifting baseline syndrome of fisheries. Trends Ecol. Evol. 10, 430.

Pellegrini, A.F.A., McLauchlan, K.K., Hobbie, S.E., Mack, M.C., Marcotte, A.L., Nelson, D.M., Perakis, S.S., Reich, P.B., Whittinghill, K., 2020. Frequent burning causes large losses of carbon from deep soil layers in a temperate savanna. J. Ecol. 108, 1426-1441. https://doi.org/10.1111/1365-2745.13351

Peluso, N.L., Vandergeest, P., 2020. Writing Political Forests. Antipode 52, 1083-1103. https://doi.org/10.1111/anti.12636

Peluso, N.L., Vandergeest, P., 2011. Political ecologies of war and forests: Counterinsurgencies and the making of national natures. Ann. Assoc. Am. Geogr. 101, 587-608. https://doi.org/10.1080/00045608.2011.560064

Perino, A., Pereira, H.M., Navarro, L.M., Fernández, N., Bullock, J.M., Ceauşu, S., Cortés-Avizanda, A., van Klink, R., Kuemmerle, T., Lomba, A., Pe'er, G., Plieninger, T., Rey Benayas, J.M., Sandom, C.J., Svenning, J.-C., Wheeler, H.C., 2019. Rewilding complex ecosystems. Science (80-. ). 364, eaav5570. https://doi.org/10.1126/science.aav5570

Petersen, R., Aksenov, D., Esipova, E., Goldman, E., Harris, N., Kuksina, N., Kurakina, I., Loboda, T., Manisha, A., Sargent, S., Shevade, V., 2016. Mapping tree plantations with mutlispectral imagery: preliminary results for seven tropical countries. Tech. Note 185-205.

Petersen, A.C. 2000. Models as Technological Artefacts. Social Studies of Science, 793-799. https://doi.org/10.1177/030631200030005006

Phelps, J., Friess, D.A., Webb, E.L., 2012. Win-win REDD+ approaches belie carbon-biodiversity trade-offs. Biol. Conserv. 154, 53-60. https://doi.org/10.1016/j.biocon.2011.12.031

Poorter, L., van der Sande, M.T., Thompson, J., Arets, E.J.M.M., Alarcón, A., Álvarez-Sánchez, J., Ascarrunz, N., Balvanera, P., Barajas-Guzmán, G., Boit, A., Bongers, F., Carvalho, F.A., Casanoves, F., Cornejo-Tenorio, G., Costa, F.R.C., de Castilho, C. V., Duivenvoorden, J.F., Dutrieux, L.P., Enquist, B.J., Fernández-Méndez, F., Finegan, B., Gormley, L.H.L., Healey, J.R., Hoosbeek, M.R., Ibarra-Manríquez, G., Junqueira, A.B., Levis, C., Licona, J.C., Lisboa, L.S., Magnusson, W.E., Martínez-Ramos, M., Martínez-Yrizar, A., Martorano, L.G., Maskell, L.C., Mazzei, L., Meave, J.A., Mora, F., Muñoz, R., Nytch, C., Pansonato, M.P., Parr, T.W., Paz, H., Pérez-García, E.A., Rentería, L.Y., Rodríguez-Velazquez, J., Rozendaal, D.M.A., Ruschel, A.R., Sakschewski, B., Salgado-Negret, B., Schietti, J., Simões, M., Sinclair, F.L., Souza, P.F., Souza, F.C., Stropp, J., ter Steege, H., Swenson, N.G., Thonicke, K., Toledo, M., Uriarte, M., van der Hout, P., Walker, P., Zamora, N., Peña-Claros, M., 2015. Diversity enhances carbon storage in tropical forests. Glob. Ecol. Biogeogr. 24, 1314-1328. https://doi.org/10.1111/geb.12364

Poulter, B., Frank, D., Ciais, P., Myneni, R.B., Andela, N., Bi, J., Broquet, G., Canadell, J.G., Chevallier, F., Liu, Y.Y., Running, S.W., Sitch, S., Van Der Werf, G.R., 2014. Contribution of semi-arid ecosystems to interannual variability of the global carbon cycle. Nature 509, 600-603. https://doi.org/10.1038/nature13376

Ratnam, J., Bond, W.J., Fensham, R.J., Hoffmann, W.A., Archibald, S., Lehmann, C.E.R., Anderson, M.T., Higgins, S.I., Sankaran, M., 2011. When is a "forest" a savanna, and why does it matter? Glob. Ecol. 
Biogeogr. 20, 653-660. https://doi.org/10.1111/j.1466-8238.2010.00634.x

Rotenberg, E., Yakir, D., 2010. Contribution of semi-arid forests to the climate system. Science (80-. ). 327, $451-455$.

Rundel, P.W., Arroyo, M.T.K., Cowling, R.M., Keeley, J.E., Lamont, B.B., Vargas, P., 2016. Mediterranean biomes: Evolution of their vegetation, floras, and climate. Annu. Rev. Ecol. Evol. Syst. 47, 383-407. https://doi.org/10.1146/annurev-ecolsys-121415-032330

Sanders, A.J.P., Hyldmo, H. da S., Prasti H., R.D., Ford, R.M., Larson, A.M., Keenan, R.J., 2017. Guinea pig or pioneer: Translating global environmental objectives through to local actions in Central Kalimantan, Indonesia's REDD+ pilot province. Glob. Environ. Chang. 42, 68-81. https://doi.org/10.1016/j.gloenvcha.2016.12.003

Schweiger, A.H., Irl, S.D.H., Svenning, J., Higgins, S.I., 2020. Dynamic management needs for long-lived, sporadically recruiting plant species in human-dominated landscapes. Plants, People, Planet 2, 1-15. https://doi.org/10.1002/ppp3.10096

Schweiger, A.H., Svenning, J., 2019. Analogous losses of large animals and trees, socio-ecological consequences, and an integrative framework for rewilding-based megabiota restoration. People Nat. 2, 29-41. https://doi.org/10.1002/pan3.10066

Seddon, N., Chausson, A., Berry, P., Girardin, C.A.J., Smith, A., Turner, B., 2020a. Understanding the value and limits of nature-based solutions to climate change and other global challenges. Philos. Trans. R. Soc. B Biol. Sci. 375, 20190120. https://doi.org/10.1098/rstb.2019.0120

Seddon, N., Daniels, E., Davis, R., Chausson, A., Harris, R., Hou-Jones, X., Huq, S., Kapos, V., Mace, G.M., Rizvi, A.R., Reid, H., Roe, D., Turner, B., Wicander, S., 2020b. Global recognition of the importance of nature-based solutions to the impacts of climate change. Glob. Sustain. 3, e15. https://doi.org/10.1017/sus.2020.8

Seymour, F., 2020. Seeing the forests as well as the (trillion) trees in corporate climate strategies. One Earth 2, 390-393. https://doi.org/10.1016/j.oneear.2020.05.006

Sivaramakrishnan, K., 1995. Colonialism and Forestry in India: Imagining the Past in Present Politics. Comp. Stud. Soc. Hist. 37, 3-40. https://doi.org/10.1017/S0010417500019514

Soto-Navarro, C., Ravilious, C., Arnell, A., De Lamo, X., Harfoot, M., Hill, S.L.L., Wearn, O.R., Santoro, M., Bouvet, A., Mermoz, S., Le Toan, T., Xia, J., Liu, S., Yuan, W., Spawn, S.A., Gibbs, H.K., Ferrier, S., Harwood, T., Alkemade, R., Schipper, A.M., Schmidt-Traub, G., Strassburg, B., Miles, L., Burgess, N.D., Kapos, V., 2020. Mapping co-benefits for carbon storage and biodiversity to inform conservation policy and action. Philos. Trans. R. Soc. B Biol. Sci. 375. https://doi.org/10.1098/rstb.2019.0128

Stern, N., 2007. The economics of climate change: The stern review. https://doi.org/10.1017/CBO9780511817434

Stilgenbauer, J., McBride, J.R., 2010. Reconstruction of urban forests in Hamburg and Dresden after World War II. Landsc. J. 29, 144-160. https://doi.org/10.3368/lj.29.2.144

Streitberger, M., Hermann, G., Kraus, W., Fartmann, T., 2012. Modern forest management and the decline of the Woodland Brown (Lopinga achine) in Central Europe. For. Ecol. Manage. 269, 239-248. https://doi.org/10.1016/j.foreco.2011.12.028

Svenning, J.C., 2020. Rewilding should be central to global restoration efforts. One Earth 3, 657-660. https://doi.org/10.1016/j.oneear.2020.11.014

Swann, A.L., Fung, I.Y., Levis, S., Bonan, G.B., Doney, S.C., 2010. Changes in arctic vegetation amplify high-latitude warming through the greenhouse effect. Proc. Natl. Acad. Sci. U. S. A. 107, 1295-1300. 
Swanson, H.A., Svenning, J.C., Saxena, A., Muscarella, R., Franklin, J., Garbelotto, M., Mathews, A.S., Saito, O., Schnitzler, A.E., Serra-Diaz, J.M., Tsing, A.L., 2021. History as grounds for interdisciplinarity: promoting sustainable woodlands via an integrative ecological and socio-cultural perspective. One Earth 4, 226-237. https://doi.org/10.1016/j.oneear.2021.01.006

Szabó, P., 2010. Why history matters in ecology: An interdisciplinary perspective. Environ. Conserv. 37, 380-387. https://doi.org/10.1017/S0376892910000718

Tabor, K., Hewson J.. 2018. The Evolution of Remote Sensing Applications Vital to Effective Biodiversity Conservation and Sustainable Development." Satellite Remote Sensing for Conservation Action: Case Studies from Aquatic and Terrestrial Ecosystems, pp. 274.

Tarnocai, C., Canadell, J.G., Schuur, E.A.G., Kuhry, P., Mazhitova, G., Zimov, S., 2009. Soil organic carbon pools in the northern circumpolar permafrost region. Global Biogeochem. Cycles 23, 1-11. https://doi.org/10.1029/2008GB003327

Tong, X., Brandt, M., Yue, Y., Ciais, P., Rudbeck Jepsen, M., Penuelas, J., Wigneron, J.P., Xiao, X., Song, X.P., Horion, S., Rasmussen, K., Saatchi, S., Fan, L., Wang, K., Zhang, B., Chen, Z., Wang, Y., Li, X., Fensholt, R., 2020. Forest management in southern China generates short term extensive carbon sequestration. Nat. Commun. 11, 1-10. https://doi.org/10.1038/s41467-019-13798-8

Tropek, R., Sedláček, O., Beck, J., Keil, P., Musilová, Z., Šímová, I., Storch, D., 2014. Response to comment on "High-resolution global maps of 21st-century forest cover change." Science (80-. ). 344. https://doi.org/10.1126/science. 1248817

Tsing, A.L., 2005, Friction: An Ethnography of Global Connection. Princeton University Press, Princeton, New Jersey.

Tufte, E. 2006. The Visual Display of Quantitative Information, Cheshire, CT, 1983; see also F.C. von Roten, Do we needa public understanding of statistics?,Public Understanding of Science, 15: 243249.

Turnhout, E., Stuiver, M., Judith, J., Harms, B., Leeuwis, C., 2013. New roles of science in society: Different repertoires of knowledge brokering. Sci. Public Policy 40, 354-365. https://doi.org/10.1093/scipol/scs114

UNEP and FAO, 2020. The State of the World's Forests 2020. Forests, biodiversity and people. Rome.

Van Hecken, G., Bastiaensen, J., 2010. Payments for ecosystem services: Justified or not? A political view. Environ. Sci. Policy 13, 785-792. https://doi.org/10.1016/j.envsci.2010.09.006

van Noordwijk, M., 2020. Prophets, profits, prove it: social forestry under pressure. One Earth 2, 394-397. https://doi.org/10.1016/j.oneear.2020.05.008

van Swaay, C., Warren, M., Loïs, G., 2006. Biotope use and trends of European butterflies. J. Insect Conserv. 10, 189-209. https://doi.org/10.1007/s10841-006-6293-4

Veldman, J.W., Aleman, J.C., Alvarado, S.T., Anderson, T.M., Archibald, S., Bond, W.J., Boutton, T.W., Buchmann, N., Buisson, E., Canadell, J.G., Dechoum, M. de S., Durigan14, M.H., Giselda, D.-T., Ewel, J.J., Fernandes, G.W., Fidelis, A., Fleischman, F., Good, S.P., Griffith, D.M., Hermann, J.-M., Hoffmann, W.A., Stradic, S. Le, Lehmann, C.E.R., Mahy, G., Nerlekar, A.N., Nippert, J.B., Noss, R.F., Osborne, C.P., Overbeck, G.E., Parr, C.L., Pausas, J.G., Pennington, R.T., Perring, M.P., Putz, F.E., Ratnam, J., Sankaran, M., Schmidt, I.B., Schmitt, C.B., Silveira, F.A.O., A. Carla Staver, Nicola Stevens, C.J., Still, C., Strömberg, A.E., Temperton, V.M., Morgan, J.V., Zaloumis, N.P., 2019. Comment on "The global tree restoration potential." Science (80-. ). 366, eaay797. https://doi.org/10.1126/science.aaz0111 
Watson, J.E.M., Evans, T., Venter, O., Williams, B., Tulloch, A., Stewart, C., Thompson, I., Ray, J.C., Murray, K., Salazar, A., McAlpine, C., Potapov, P., Walston, J., Robinson, J.G., Painter, M., Wilkie, D., Filardi, C., Laurance, W.F., Houghton, R.A., Maxwell, S., Grantham, H., Samper, C., Wang, S., Laestadius, L., Runting, R.K., Silva-Chávez, G.A., Ervin, J., Lindenmayer, D., 2018. The exceptional value of intact forest ecosystems. Nat. Ecol. Evol. 2, 599-610. https://doi.org/10.1038/s41559-0180490-x

Wesselink, A., Buchanan, K.S., Georgiadou, Y., Turnhout, E., 2013. Technical knowledge, discursive spaces and politics at the science-policy interface. Environ. Sci. Policy 30, 1-9. https://doi.org/10.1016/j.envsci.2012.12.008

Wiersum, 1999. Social forestry: changing perspectives in forestry science or practice? Thesis Wageningen University.

Wigley, B.J., Augustine, D.J., Coetsee, C., Ratnam, J., Sankaran, M., 2020. Grasses continue to trump trees at soil carbon sequestration following herbivore exclusion in a semiarid African savanna. Ecology 0, $1-$ 10. https://doi.org/10.1002/ecy.3008

World Economic Forum, 2020. Global Risk Report 2020. Geneva, Switzerland.

Yepez, E.A., Williams, D.G., Scott, R.L., Lin, G., 2003. Partitioning overstory and understory evapotranspiration in a semiarid savanna woodland from the isotopic composition of water vapor. Agric. For. Meteorol. 119, 53-68. https://doi.org/10.1016/S0168-1923(03)00116-3

Ylänne, H., Kaarlejärvi, E., Väisänen, M., Männistö, M.K., Ahonen, S.H.K., Olofsson, J., Stark, S., 2020. Removal of grazers alters the response of tundra soil carbon to warming and enhanced nitrogen availability. Ecol. Monogr. 90, 1-13. https://doi.org/10.1002/ecm.1396

Zhang, D., Wang, H., Wang, X., Lü, Z., 2020. The reference data for accuracy assessment of the Global Forest Watch tree cover 2000 in China. Data Br. 29, 105238. https://doi.org/10.1016/j.dib.2020.105238

Zhang, Y., Sui, B., Shen, H., Ouyang, L., 2019. Mapping stocks of soil total nitrogen using remote sensing data: A comparison of random forest models with different predictors. Comput. Electron. Agric. 160, 23-30. https://doi.org/10.1016/j.compag.2019.03.015 